\title{
Water Balances, Floods and Sediment Transport in the Hindu Kush-Himalayas
}

Data analyses, modelling and comparison of selected meso-scale catchments

Juerg Merz
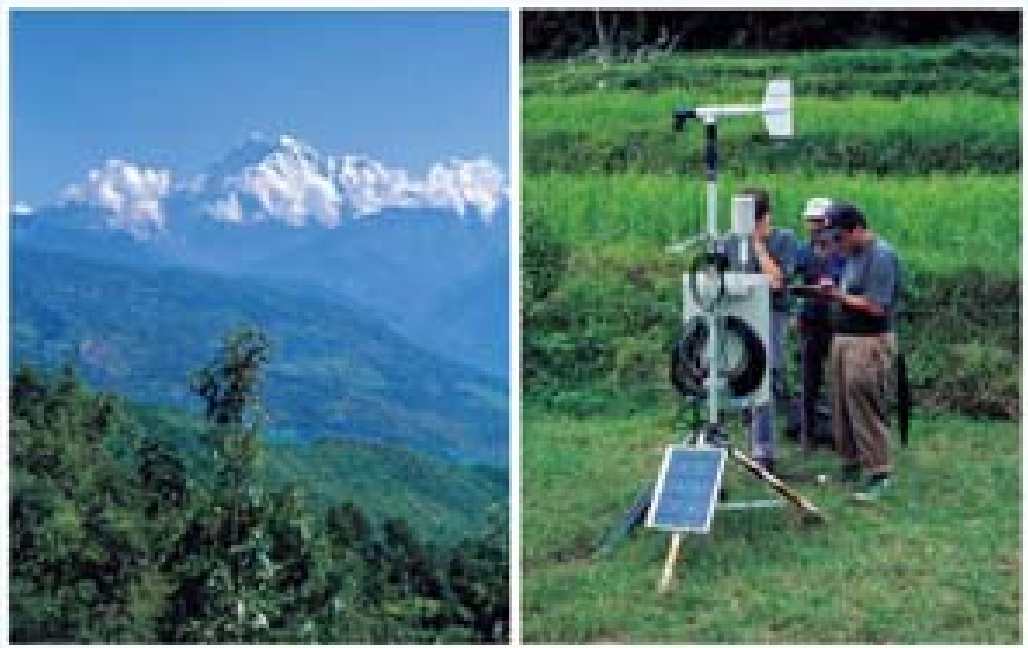

University of Berne, Switzerland • Institute of Geography 


\section{about ICIMOD}

\section{ICIMOD}

The International Centre for Integrated Mountain Development (ICIMOD) is an independent 'Mountain Learning and Knowledge Centre' serving the eight countries of the Hindu Kush-Himalayas - Afghanistan

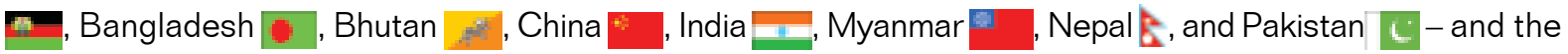
global mountain community. Founded in 1983, ICIMOD is based in Kathmandu, Nepal, and brings together a partnership of regional member countries, partner institutions, and donors with a commitment for development action to secure the future of the Hindu Kush-Himalayas. The primary objective of the Centre is to promote the development of economically and environmentally sound mountain ecosystems and to improve the living standards of mountain populations. 


\section{Water Balances, Floods and Sediment Transport in the Hindu Kush-Himalayas}




\section{GEOGRAPHICA BERNENSIA}

Published by:

Lecturers of the Institute of Geography, University of Berne, Switzerland

Series:

Series A African Studies Series

Series B Excursions, Field Seminars and Courses (in German)

Series E Development and Environment Reports

Series G Basic Research (mostly in German)

Series P Applied Geography (in German)

Series S Geography in Schools (in German)

Series U Textbooks in Geography, University Level (in German)

\section{G 72}

Arbeitsgemeinschaft GEOGRAPHICA BERNENSIA in cooperation with Geographical Society of Berne, Switzerland Hallerstrasse 12, CH-3012 Bern

Published by Institute of Geography, University of Berne, Switzerland 


\section{Water Balances, Floods and Sediment Transport in the Hindu Kush-Himalayas}

Data Analyses, Modelling and Comparison of Selected Meso-scale Catchments

Juerg Merz 


\section{Copyright $\odot 2004$}

Geographica Bernensia, University of Berne

ISBN 3-906151-75-1

ICIMOD, Nepal

ISBN 92-9115-751-1

Published by

International Centre for Integrated Mountain Development for the University of Berne

G.P.O. Box 3226

Kathmandu, Nepal

\section{Editorial Team}

Rosemary Thapa (Consultant Editor)

Greta Rana (Senior Editor)

Dharma R. Maharjan (Technical Support and Layout Design)

Printed and bound in Nepal by

Hill Side Press $(P)$ Ltd.

Kathmandu

The views and interpretations in this paper are those of the contributor(s). They are not attributable to the University of Berne or the International Centre for Integrated Mountain Development (ICIMOD) and do not imply the expression of any opinion concerning the legal status of any country, territory, city or area of its authorities, or concerning the delimitation of its frontiers or boundaries, or the endorsement of any product. 
This report was accepted by the Philosophisch-naturwissenschaftlichen Fakultät Berne (Faculty of Natural Sciences, University of Berne) as a PhD thesis on the 6 November 2003.

This thesis was produced under the People and Resource Dynamics in Mountain Catchments of the Hindu Kush-Himalayas (PARDYP) Project; a project funded by the Swiss Agency for Development and Cooperation (SDC) and the International Development Research Centre (IDRC). PARDYP is implemented by the International Centre for Integrated Mountain Development (ICIMOD).

Printing of this publication was supported by

- Foundation Marchese Francesco Medici del Vascello

- People and Resource Dynamics in Mountain Watersheds of the Hindu KushHimalayas (PARDYP) Project

Fuer meinen Grossvater Werner Merz

The following software packages were used by the author for this study.

- MSWord $2000 \quad$ word processing

- MSExcel 2000 tabulation of data, graphics and basic statistics

- SPSS $10.0 \quad$ advanced statistics

- ArcView 3.2 mapping and GIS applications

- CorelDraw 9 graphics

- MSAccess 2000 data management

- HYMOS 4.03 data management and advanced hydrological analyses 


\section{Foreword}

According to the first proposal, the research for this thesis should have been carried out entirely in the Yarsha Khola catchment area, comprising a field-based and in-depth process understanding of streamflow generation in a middle mountain catchment of the Hindu Kush-Himalayas. However, the political situation in Nepal did not allow extended field work, particularly after the incident at the Yarsha Khola field office on February 2, 1999. A second proposal was drafted one year into the work, detailing preparations for the first extended field season, due to begin in March 1999 with the onset of the pre-monsoon rains. This proposal aimed to review the existing database of the Jhikhu Khola catchment and attempted to synthesise information already collected. While field-based work in the Yarsha Khola catchment may have engendered a more proactive approach, with more chances to generate 'new knowledge', the reactive approach that was subsequently adopted for work in the Jhikku Khola catchment is probably more helpful in terms of understanding how far we have reached in the project over the years. The new knowledge in this study is the detailed interpretation of information and data from different surveys, measurement campaigns, and long-term data monitoring. 


\section{Acknowledgements}

Over my five years in the PARDYP project at ICIMOD, I have met many interesting and challenging people who have all contributed to this thesis by stimulating my thinking. Thanks are due to all of them. I have learned a tremendous amount, not only through carrying out this study, but also from the day-to-day activities of a regional research-for-development project.

It was thanks to Rolf Weingartner that I had the chance to work an initial three months in India, where I first got a taste of Asia. Rolf then convinced me to do a PhD and to spend a number of years in Nepal. This was the best thing that could have happened to me. Thank you, Rolf.

The project activities would have been only half the fun without the regional coordinators. Firstly, I really enjoyed working with Richard Allen, in whom I had a great supporter of most of my ideas, and with whom I enjoyed great days in the different PARDYP catchments. With his successor, Roger White, I remember many discussions on institutional capacities, sediment, and collaboration in development. I would also like to thank him for his comments on the first draft of this thesis.

PARDYP Nepal was a fine host for all these years and I hope that I did not only take, but was also able to feed something back into the team. First of all, I would like to thank Pravakar B. Shah, the Nepal Country Coordinator, with whom I had so many interesting discussions, not only in the office, but also during lunch. He read this thesis from beginning to end and offered many valuable comments. I am highly indebted to the Water and Erosion Studies team, including Gopal Nakarmi, Pradeep M. Dangol, Madhav P. Dhakal, Bhawani S. Dongol, Tirtha R. Adhikari, Birendra R. Adhikari, and Smita Shrestha. I had to bother them many times with requests for data or for scanning figures. I hope that I did not only take, but also give.

I would also like to acknowledge the friendly working atmosphere I was able to enjoy thanks to all the remaining PARDYP staff - Bhuban Shrestha, Bandana Prajapati Merz, Madhav P. Pandey, Prem R. Neupane, Giri B. Shrestha, Balgopal Shrestha, Samma Shakya, Raju Khadga, Yamuna Galey, Radha Karki, Megh R. Rai, Tika S. Karki, and Renu Lama.

I always enjoyed my time in the field, both in the Yarsha Khola as well as the Jhikhu Khola catchments. The respective field assistants made these stays very comfortable. Thanks to Krishna R. Adhikari, Ramesh Lamichane, Krishna P. Dahal, Ramu P. Dahal, Hari Jirel, Bijaya Danuwar, and Dhurba Dhungana. Unfortunately, field days were few and far between in the last two years.

Thomas Hofer and his family provided me with a warm welcome and a comfortable home during my first weeks in Nepal, which was greatly appreciated. I hope that I carried on the work initiated by Thomas in the way he would have done it. Thanks also to Hans Schreier and Sandra Brown from the University of British Colombia (UBC) for their critical inputs, their support in multimedia applications, and the numerous discussions on soil-water-land-use linkages and other components of the project.

Sheshe - Prof. Xu Jianchu, Gao Fu, Ma Xing, and Duan Shangbiao from PARDYP China. Gao Fu in particular was very helpful whenever I needed some additional information on the Xizhuang catchment.

Dhanyabad - Dr. B.P. Kothyari, Sanjeev Bhuchar, Venugopalan Nair, Keshav Ramprasad, P.K. Verma, and B.K. Joshi from PARDYP India.

Shukria - Hakim Shah, Mohammad Jehangir, Welayat Khan, and Sohail Zokaib from PARDYP Pakistan.

In the catchments a number of local readers ensured quality data collection every day, which is highly appreciated. Sheshe, dhanyabad, and shukria. 
Whenever I was in Switzerland, the Hydrology Group welcomed me warmly, thanks to Dori Vuillemin. All the students who came to Nepal, be it for practical experience or for their theses, enriched the day-to-day activities of the project. Beat Tschanz, Philipp Wuethrich, Yvonne Voegeli, Monika Schaffner, Jos Aeschbacher, and Mirco Auer - I hope you enjoyed a useful and enjoyable time here in Nepal.

It is thanks to Alex Hermann that the maps in this thesis are clear and readable.

During my stays in Switzerland I very much enjoyed the company of my Swiss friends and the hospitality of Christine and Martin Schor. Cheers!

Regarding the modelling, I would like to acknowledge the support of Massimiliano Zappa and Joachim Gurtz from the Institute for Atmospheric and Climate Science at the Federal Institute of Technology (ETH) in Zurich. They provided the PREVAH model and gave valuable support during modelling. Satish Bastola from the Institute for Engineering at Tribhuvan University calibrated the UBC model and taught me everything about this model, as well as about the Tank model. Thank you. The use of the UBC Catchment Modelling system, developed by the Mountain Hydrology Group, Department of Civil Engineering, University of British Columbia, Vancouver, Canada, is likewise acknowledged.

I am highly indebted to the donors of the project, SDC (Swiss Agency for Development and Cooperation) and IDRC (International Development Research Centre). Felix von Sury, Karl Schuler, and Carmen Thoenissen from SDC, and John Graham and Liz Fajber from IDRC, were staunch supporters of the project. Furthermore, I would like to acknowledge the financial support of the Jeune Chercheur scholarship of SDC, thanks to which I was able to travel annually to our project teams in China and Pakistan to review their progress and advise them on their water and erosion programme; and because of which I was also able to attend two interesting conferences.

ICIMOD provided me with a place to work and feel professionally at home. Thanks to all with whom I was working and with whom I was in contact during this time.

Thanks to Rosemary Thapa and Greta Rana, this publication is produced in good English. I would also like to thank Dharma R. Maharjan for his layout design.

I would also like to thank others who contributed in various ways - Peter Bitter, Suresh R. Chalise, Mandira Shrestha, Subodh Sharma, and Beatrice Shrestha.

Thanks to my parents for their support from the old home and to my parents-in-law for their support in the new home.

Bandana, most of the thanks go to you! I hope the times of early mornings, late nights, and Saturdays and Sundays on the computer are now mostly over. The biggest rainfall event in the study period $-171.8 \mathrm{~mm}$ - fell on our wedding day. I am sure this is the best omen for a hydrologist! And Nina, I am looking forward to more time with you with the LEGO, in the zoo, and with your story books. 


\section{Executive Summary}

This study is embedded in the People and Resource Dynamics of Mountain Catchments in the Hindu Kush-Himalayas Project (PARDYP). PARDYP is a regional research-for- development project, working in natural resources and watershed management. The project includes five catchments of 20 to $110 \mathrm{~km}^{2}$ across the Hindu Kush-Himalayan region, with sites in China, India, Pakistan, and two sites in Nepal.

The study examines the current situation of water resources in selected meso-scale catchments in both the biophysical and socioeconomic contexts. It focuses primarily on the Jhikhu Khola catchment (Kavrepalanchok district) in the middle mountains of Nepal, and compares the results with the Yarsha Khola catchment (Dolakha district), as well as with the PARDYP catchments in China, India, and Pakistan. It aims to contribute to increased understanding of water resources and water-related processes, such as soil erosion and land degradation, as well as contributing towards knowledge about integrated catchment development with minimised water-induced land degradation and minimised water resource degradation. The main components of the study are as follow:

- runoff generation and floods,

- sediment mobilisation and transport,

- water availability for domestic and agricultural purposes

- impact of future change on water resources and related processes, and

- synthesis and development of a framework for comparison of catchments in the region.

Research was based on the results of various surveys and mapping campaigns carried out in the catchments, and on detailed hydro-meteorological data collected according to the nested approach. This approach allowed the investigation of processes from the micro- to the meso-scale, that is, from plot to catchment level. It also determined the scale dependency of these processes.

To begin with, the inherent conditions of the catchments regarding flood generation, land degradation, and water scarcity from the perspectives of catchment characteristics, human settings, and processes were assessed. According to these criteria, the PARDYP Nepal catchments are in a fragile and vulnerable region. Water scarcity is caused mainly by the seasonality of water resources and their management. Precipitation is highly seasonal, with 75 to $80 \%$ of the rainfall occurring during the monsoon season, and 10 to $15 \%$ falling during the pre-monsoon season. The rest of the year is virtually dry. Evapotranspiration rates peak during the pre-monsoon season, making March to April the driest time of the year, as runoff also reaches its lowest point during this time. Water supply for domestic use is at a minimum during this time and many households face hardship fetching water. In terms of water quality concerns, the peak risk season is the early monsoon, with the highest microbiological and chemical contamination. Local water use for agriculture is, in general, well adapted to seasonality. Even so, farmers perceive there to be a water shortage since they are not able to grow any additional crops during this time. Farmers at the tail end of irrigation systems receive inadequate water supply even during the wet season. The time of highest risk for farmers is the time between the first pre-monsoon rains and the onset of the monsoon, as this is the time when maize is planted and the rice nurseries are prepared. Agriculture is also vulnerable in the winter season, when wheat and potatoes are grown. Rainfed crops can be damaged in dry conditions, and little rainfall might mean that one less crop can be planted on irrigated land. In addition, the growing number of farmers producing cash crops puts an additional stress on water resources. These issues suggest that in future the focus should be on improved management of irrigation systems, catchment-based management of water resources, appropriate technologies to reduce water demand and increase water availability during the dry season, and improved water quality management.

Floods are generated mainly in the monsoon season. In general, it is during this time that the most intense rainfall events with the highest intensities and volumes occur. It was shown that runoff generation on degraded areas as well as on grasslands contributes most to flood volumes, while 
rainfed agricultural land only contributes marginally to flood behaviour. It is important to keep this in mind for the discussion on the impact of Himalayan farmers on downstream flooding. Cultivated land in general has a beneficial impact on flood generation, while degraded land and grassland increases the volume as well as the peaks. A cluster approach defined rainfall intensity and volume as the main determinants for flood generation. On degraded land and grassland, infiltration excess overland flow is expected to produce surface runoff; while, on agricultural land, it is largely saturation excess overland flow that is responsible for producing surface runoff. At the catchment level, processes similar to those on degraded land contribute to flood generation. In terms of the largest flood events, no particular pattern was observed, except that these events generally occur when rainfall throughout the catchment exceeds $25 \mathrm{~mm}$, with a maximum of 30-minute rainfall intensities of $>10 \mathrm{~mm} / \mathrm{h}$; or events in pocket areas of the catchment with more than $10 \mathrm{~mm}$ rainfall and more than $20 \mathrm{~mm} / \mathrm{h}, 30$-minute intensity. In addition, it was observed that land use had no impact on the largest events. In terms of flood protection and management, downstream planning and prohibition of river channel encroachment will yield better results than small-scale land-use changes in the upland catchments.

Soil loss was shown to be greatest on degraded land, followed by agricultural land, and grassland. A difference was observed between the seasons on the agricultural land in the Jhikhu Khola catchment, while in the Yarsha Khola catchment no difference was observed. Likewise, on grassland as well as on degraded land, no difference was observed between the seasons. From a total soil loss perspective, the current soil loss rates from the agricultural land are not of major concern as they balance the natural soil development. Surface erosion on degraded patches as well as gulling on these areas produce much higher loads and are of particular concern for downstream areas. The surface soil loss, in addition to the sediment produced in the streambed and the roads, adds up to sediment loads of medium to high magnitude.

Farmers themselves do not see surface erosion from their fields as a major issue. Soil conservation activities will only be successful if farmers see an additional benefit to soil conservation, such as increased fertility, increased income, or increased fodder availability. To reduce the sediment yield from the catchments, focus should be given to the streambanks, the road network, and the degraded areas.

The study also investigated the possible impacts of future changes on established and inherent conditions under different scenarios. To date, these include increasing population, global climate change, and marginalisation or extensification of the areas. It was shown that potential climate change might lead to lower water availability in the presently critical seasons, while increased rainfall may increase the magnitude and number of flood peaks. Population growth will lead to increased water demands for domestic purposes, while an intensification in the already highly intense farming systems is less likely, and food will have to be produced elsewhere, or more focus will have to be given to staple food production in the future. The land-use scenarios could not deliver conclusive answers, as the vegetation parameters were inadequate and need to be improved with the availability of the respective data. From a methodological perspective, the distributed model PREVAH (precipitation-runoff-evapotranspiration-hydrotope model) showed the best performance with potential improvement possibilities. The Tank model was the most user-friendly model tested. These models will have to receive further attention in terms of incorporation of rainfall intensity and calculation of evapotranspiration.

For the comparison of catchments in the region, an index approach for the assessment of the three susceptibilities is proposed. The Water Poverty Index (WPI), the Flood Generation Index (FGI), and the Water Induced Degradation Index (WDI) have shown good first results during the comparison of the PARDYP Nepal catchments and could be used to compare these catchments with those in Pakistan and India. The Jhikhu Khola catchment had a lower WPI than the Yarsha Khola catchment, mainly due to fewer water resources, less access, greater use, and more adverse effects on the environment, while in the Yarsha Khola catchment the capacity score was lower.

This study concludes that the most important considerations when developing water management decision-support systems are: location with reference to potential water sources, water use, and temporal distribution of water demand and availability. 


\section{Acronyms and Abbreviations}

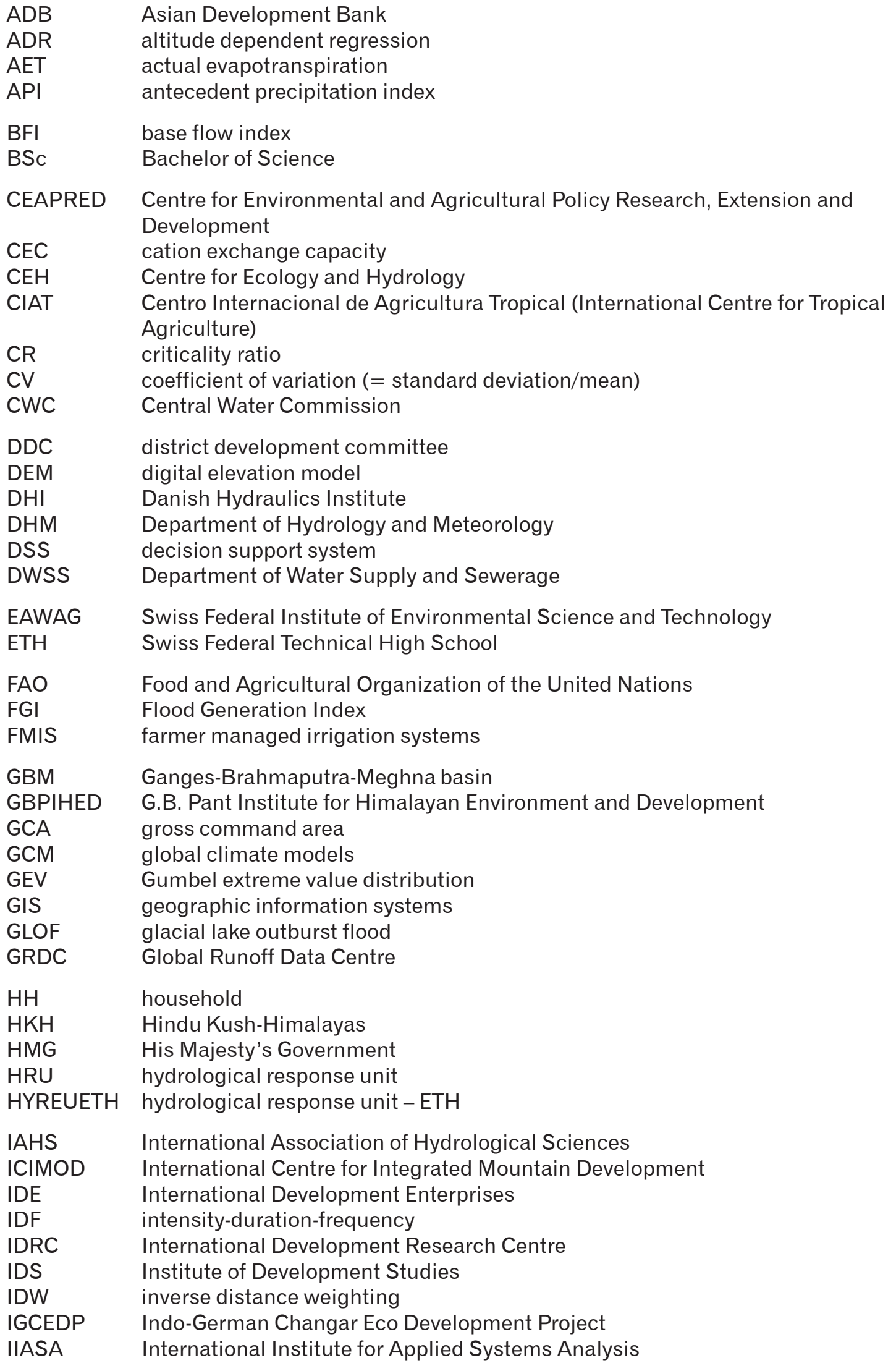




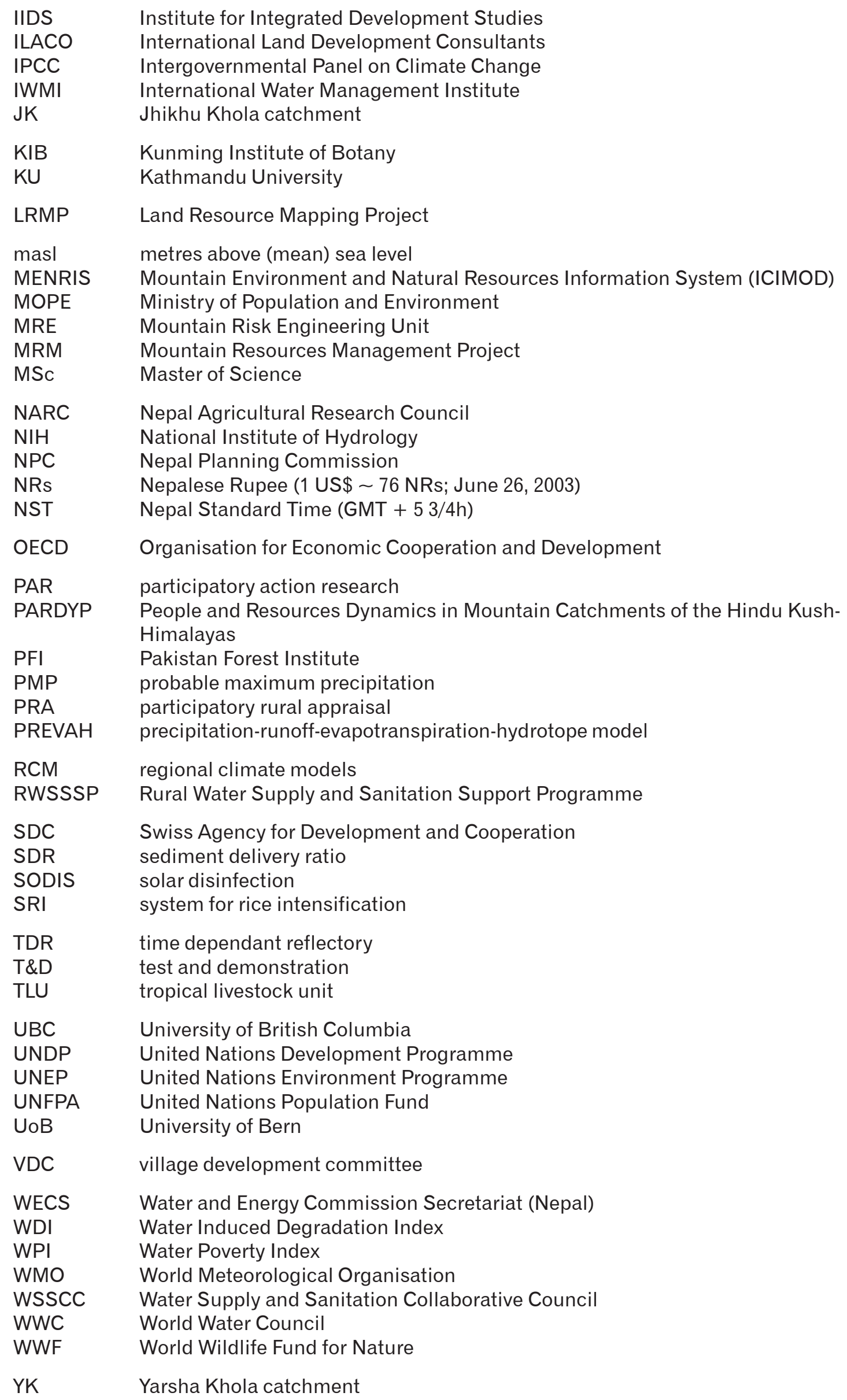




\section{Glossary}

In this report the term catchment is used as a synonym for watershed, meaning the area drained by one particular river or stream. To indicate that the discussion is focusing on part of a catchment, the term 'sub-catchment' is used. Watershed is used as the term for catchment boundary or divide.

bari

bazaar

criticality ratio

dry spell

hydrograph

hydrological response unit hyetograph

Hymos

khet

khola

kosi

kuwa

Landflucht

model calibration

model validation

rainy day

sanitation rainfed agricultural land (Nepali)

market (Nepali)

ratio of average annual water withdrawal to water availability (Alcamo et al. 2000)

a period of 15 days with no more than $1 \mathrm{~mm}$ of rain each day (Mosley and Pearson 1997)

graph of discharge as a function of time at a given station

catchment area unit with similar hydrological response

graph of rainfall as a function of time at a given station

software for environmental data management distributed by Delft Hydraulics, the Netherlands

irrigated agricultural land

river, stream (Nepali)

river (Nepali)

spring box (Nepali)

outmigration of people from rural to urban areas; urbanisation from the perspective of the rural areas

process of appropriate parameter selection (Sorooshian and Gupta 1995)

process of parameter verification on a new dataset previously not used in the calibration procedure (Sorooshian and Gupta 1995)

day with equal or more than $1 \mathrm{~mm}$ of rain per day

use of sanitary means of excreta disposal using flush toilets or pit latrines (NPC 2000) 


\section{Symbols and Units}

\section{Units}

In general SI units are used throughout this study.

\section{Symbols}

$\begin{array}{ll}\text { a } & \text { runoff coefficient } \\ \text { A } & \text { area } \\ \text { a, b, c } & \text { coefficients } \\ \text { AET } & \text { actual evapotranspiration }\end{array}$

$\mathrm{a}_{\mathrm{i}} \quad$ area of the hill slope per unit contour length that drains through point $\mathrm{i}$

$\mathrm{Al}_{10} \quad$ erosivity based on 10-minute intensity

$\mathrm{Al}_{1030 \mathrm{~m}}^{10} \quad$ erosivity based on 10 - and 3-minute intensity

$\mathrm{CD}_{i} \quad$ cost-distance value of cell $\mathrm{i}$

E east

$\mathrm{ET}_{0} \quad$ reference evapotranspiration

Ho null hypotheses

HA alternative hypotheses

$\mathrm{I}_{10 \max } \quad$ maximum 10-minute rainfall intensity during the event

$I_{30 \max }^{10 \max }$ maximum 30-minute rainfall intensity during the event

$I_{60 \max }^{30 \max }$ maximum 60-minute rainfall intensity during the event

ave

$\mathrm{I}_{\mathrm{K}}$ average rainfall intensity during the event m-minute rainfall intensity crop coefficient

number of observations

P precipitation

$\mathrm{p} \quad$ probability

$\mathrm{P}_{25} \quad$ rainfall amount after $25 \%$ of the event

$P_{50}^{25} \quad$ rainfall amount after $50 \%$ of the event

$P_{75}^{50} \quad$ rainfall amount after $75 \%$ of the event

$Q_{\max } \quad$ event peak flow

$Q_{\text {obs }} \quad$ observed discharge

$Q_{\text {sim }}^{\text {obs }} \quad$ simulated discharge

$Q_{\text {start }} \quad$ flow at the beginning of the event

$Q_{\text {tot }} \quad$ total runoff, i.e. runoff between zero and hydrograph

$\mathrm{R}_{\mathrm{i}} \quad$ relative contributing area

Sig. $\quad$ significance level

B slope

T return period

$\mathrm{t}$ time/duration

$t_{p} \quad$ rainfall event duration

$t_{0} \quad$ event duration

$t_{\text {rec }} \quad$ time between peak and start of baseflow

$t_{\text {rise }}^{\text {rec }}$

Use

time between start of hydrograph rise and peak

test statistic for U-test Wilcoxon, Man and Whitney

$\begin{array}{ll}\mathrm{w}_{\mathrm{i}} & \text { weight } \\ \text { WT } & \text { water table } \\ \mathrm{z} & \text { elevation } \\ \mathrm{z} & \text { test value }\end{array}$


All chapters are concluded with a brief synopsis targetted at development actors and policymakers. The concluding remarks, including the outlook, should be relevant to all PARDYP clients.

Chapter 1: Introduction ........................................................................ 1

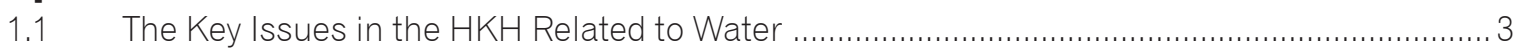

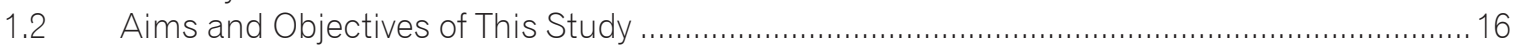

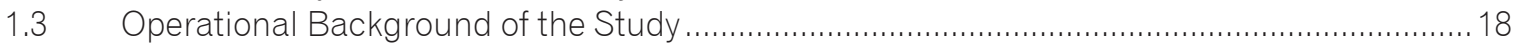

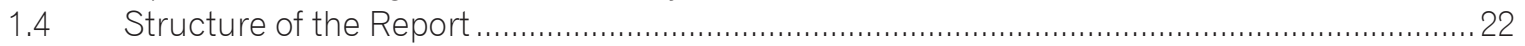

Chapter 2: The Spatial Context of the Study ...................................... 25

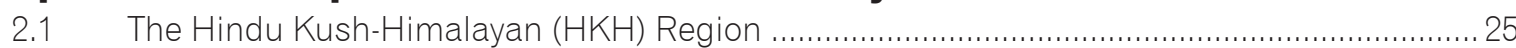

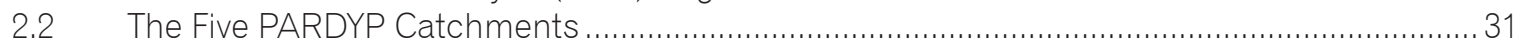

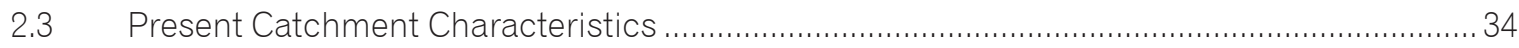

2.4 Measurement Network and Data Preparation ........................................................ 52

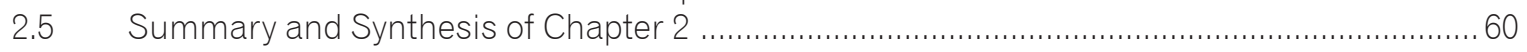

\section{Chapteer 3: Understanding the Current Status and Relevant}

Processes ......................................................................................63 63

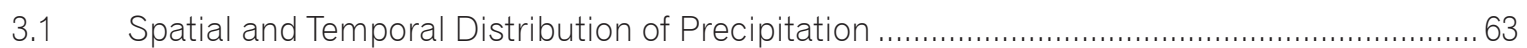

3.2 Evapotranspiration - An Important Water Loss in the Catchments .................................... 95

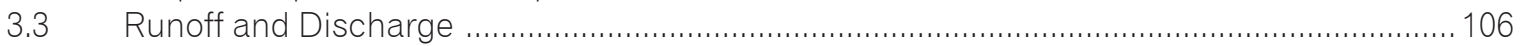

3.4 Rainfall-runoff Relationships and Event Analyses ...................................................... 127

S.5 Sediment Mobilisation and Transport .................................................................. 200

3.6 Water Demand and Supply for Human Needs ........................................................... 225

3.7 Water Balances - How much Water is Available and When? ........................................... 235

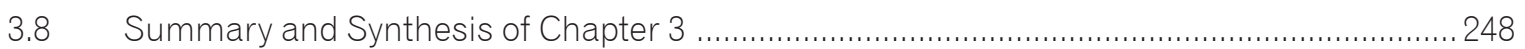

Chapter 4: Impact of Future Scenarios ......................................... 253

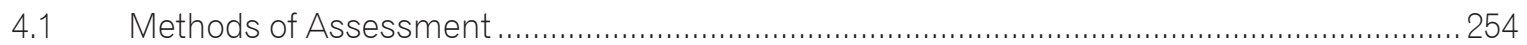

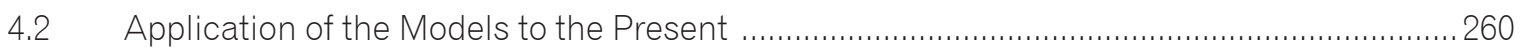

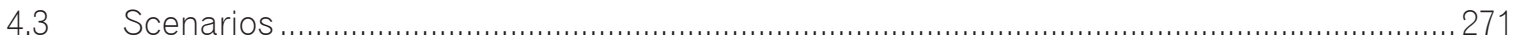

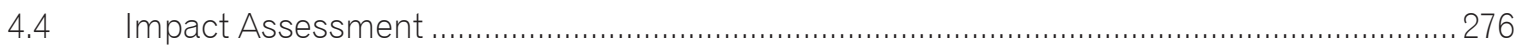

\section{Chapter 5: Synthesis - What is the State of the Water Resources} in the PARDYP Catchments? ...................................................... 283

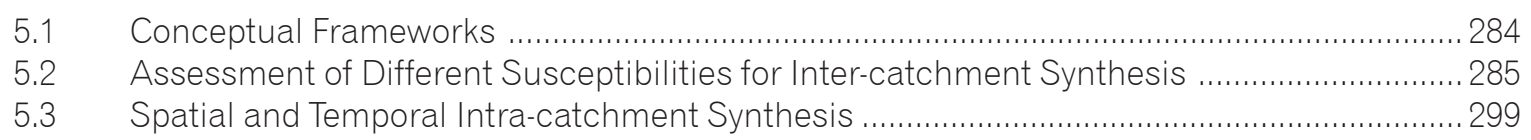

Chapter 6: Conclusion and Outlook ................................................... 305

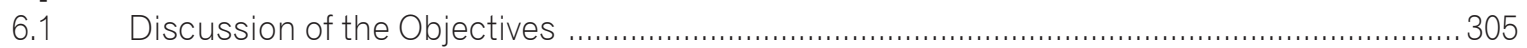

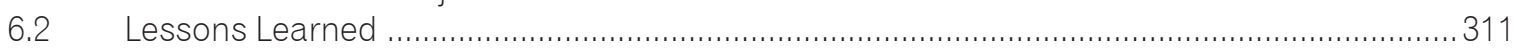

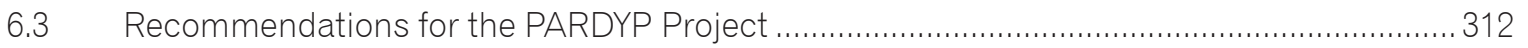

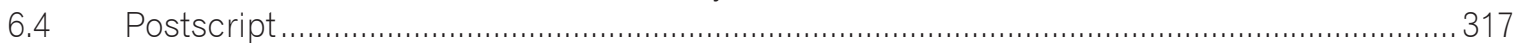

References [...................................................................................... 317 


\section{List of Figures}

1.1: Population development in the countries of the $\mathrm{HKH}$

1.2: Headlines on flood issues from the region 9

1.3: Runoff generation 10

1.4: The sediment load of selected South Asian rivers compared to the global average 13

1.5: Relationship between erosivity of rain and condition of surface vegetation throughout the year in the middle mountains of Nepal 14

1.6: Water resources in the future 16

1.7: $\quad$ Outline of the study 17

2.1: Cross-section of the Himalayas in Central Nepal 27

2.2: Climatic diagram of five stations in a) the Hindu Kush, b) the Western Himalayas, c) the Central Himalayas, d) the Eastern Himalayas, and e) the Hengduan mountains $\quad 28$

2.3: The five PARDYP catchments in the middle mountains of the $\mathrm{HKH}$

2.4: Area of selected catchments: (a) Jhikhu Khola and Yarsha Khola catchments;

(b) sub-catchments of Jhikhu Khola catchment

2.5: Relationship between length of the mainstream and mean slope of the river

2.6: Elevation distribution of (a) the main catchments, (b) the sub-catchments of the Jhikhu Khola catchment

2.7: Distribution of slope classes of (a) the main catchments and (b) the sub-catchments of the Jhikhu Khola catchment

2.8: Distribution of aspect classes in (a) main catchments and (b) sub-catchments

2.9: Comparison of the distribution functions of $\ln (a / \tan \beta)$ for $a)$ the main catchments and b) the sub-catchments

2.10: Area of different relative contribution classes

2.11: Comparison of irrigated and rainfed agricultural terraces

2.12: Land use in a) the Jhikhu Khola catchment and b) the Yarsha Khola catchment

2.13: Land use in the sub-catchments of the Jhikhu Khola catchment

2.14: Population dynamics in the Jhikhu Khola and Yarsha Khola catchments

2.15: The nested approach - a schematic explanation

2.16: Research monitoring network of the Jhikhu Khola catchment 57

2.17: Research monitoring network of the Yarsha Khola catchment 58

3.1: Long- and short-term range of precipitation in a) the Jhikhu Khola catchment and b) the Yarsha Khola catchment

3.2: Annual rainfall in the Jhikhu Khola at different stations

3.3: $\quad$ Mean monthly rainfall distribution in the Jhikhu Khola catchment, period 1993 to 2000

3.4: Coefficient of variation for a) seasonal rainfall and b) monthly rainfall in the Jhikhu Khola catchment

3.5: Relative frequency distribution of daily rainfall at Sites $6,15,16$ and comparison with long-term data set of Site 9

3.6: Days with rain below $1 \mathrm{~mm}$ and dry spells in the Jhikhu Khola catchment a) short-time series 1997 - 2000; b) long-time series 1993 - 2000

3.7: Maximum (a) and mean (b) $10 \mathrm{~min}$ intensities at different stations in the Jhikhu Khola catchment [in $\mathrm{mm} / \mathrm{h}$ ]

3.8: Monthly erosivity in the Jhikhu Khola catchment a) $\mathrm{Al}_{100}$ b) $\mathrm{Al}_{1030 \mathrm{~s}}$

3.9: Annual rainfall in the Yarsha Khola catchment at different stations $\quad 73$

3.10: Mean monthly distribution of rainfall in the Yarsha Khola catchment 74

3.11: Relative frequency distribution of daily rainfall in the Yarsha Khola catchment 74

3.12: Variability of a) seasonal and b) monthly rainfall in the Yarsha Khola catchment 75

3.13: Dry spells between 1998 and 2000 in the Yarsha Khola catchment 75

3.14: Mean (a) and $\max (\mathrm{b})$ 10-minute rainfall intensity in the Yarsha Khola
catchment [in $\mathrm{mm} / \mathrm{h}$ ]

3.15: Monthly erosivity indices in the Yarsha Khola catchment: a) $\mathrm{Al}_{10}$, b) $\mathrm{Al}_{1030 \mathrm{~m}} \quad 76$

3.16: Annual and seasonal elevation-rainfall amount relationships for the Jhikhu 7

3.17: Isohyets of annual rainfall in the Jhikhu Khola, 1993 to $2000 \quad 79$

3.18: Areal rainfall of the Jhikhu Khola catchment and its sub-catchments, 1993 to $2000 \quad 80$ 
3.19: $\mathrm{Al}_{10}$ (a) and $\mathrm{Al}_{1030}$ (b) (sorted according to size) in relation to elevation, Jhikhu Khola catchment

3.20: Observed rainfall relationships with elevation

3.21: Annual and seasonal elevation-rainfall amount relationships for the Yarsha Khola catchment, 1998 to 2000

3.22: Isohyets, 1998 to 2000, Yarsha Khola catchment

3.23: Areal rainfall in the Yarsha Khola catchment and selected sub-catchments

3.24: Erosivity index $\mathrm{Al}_{10}$ in relation to altitude, Yarsha Khola catchment

3.25: Rainfall-elevation relationships in the Yarsha Khola catchment these, Jhikhu Khola catchment

3.27: Probabilities for monthly rainfall of different amounts in a 10-year period, Site $12(1976$ - 2000), Jhikhu Khola catchment

3.28: Theoretical recurrence probabilities for daily maximum rainfall at Sites 6 :

(a) and 15 (b) compared with long-term data sets at Sites 12 (c) and 9 (d)

3.29: Comparison of calculated PMP with extreme one-day events and empirical relationship between PMP and elevation by Tahal Consulting Engineers (2002)

3.30: IDF curve for Sites 6 and 15 in the Jhikhu Khola catchment

3.31: Comparison of the IDF curves with the empirical IDF of Chyurlia (1984)

3.32: Seasonal trends in potential evapotranspiration at selected elevations of Nepal Jhikhu Khola catchment

3.34: Annual temperature variation: a) Site 12, period 1997- 2000; b) Site 15, period 1993 - 2000

3.35: Diurnal temperature variation in different months, Site 12, Jhikhu Khola catchment

3.36: Temperature differences according to aspect at different elevation zones

3.37: Annual mean-minimum-maximum temperatures at different stations in the Yarsha Khola catchment

3.38: Annual temperature variation at Site 7 of Yarsha Khola, period 1998 - 2000

3.39: Diurnal temperature variation, Site 7, Yarsha Khola catchment

3.40: Wind speed in the Jhikhu (a) and Yarsha Khola (b) catchments

3.41: Comparison of measured with calculated humidity, Site 7 Yarsha Khola

3.42: Comparison of $\mathrm{ET}_{0}$ determined by measured net radiation and calculated net radiation at Site 7 in Yarsha Khola catchment and Godavari T\&D

3.43: Annual reference evapotranspiration data of the Jhikhu and Yarsha Khola catchments compared with calculations of other authors

Mean daily reference evapotranspiration at the main stations of both catchments Isopleths of ET in the Jhikhu Khola catchment for 1993 to 2000

3.46: Isopleths of $\mathrm{ET}_{0}$ in the Yarsha Khola catchment for 1998 to 2000

3.47: Four major river basins in Nepal

3.48: Seasonal runoff from erosion plots under different land use from 1998 to 2000

3.52: Seasonal (a) and monthly (b) runoff from erosion plots on different land use 1998 - 2000

3.53: Monthly runoff coefficients on erosion plots from the Yarsha Khola catchment:

a) monthly mean, b) monthly maximum

3.54: Cumulative runoff, Yarsha Khola catchment

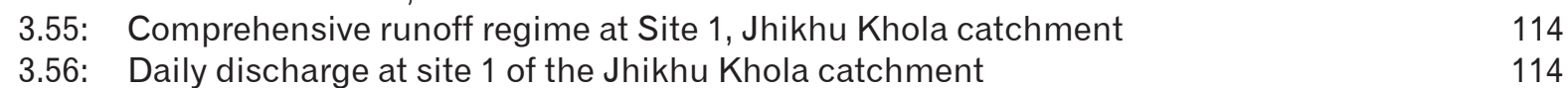

3.57: Temporal variability on the basis of monthly data, Site 1, Jhikhu Khola catchment $\quad 115$

3.58: Comprehensive runoff regime at Site 1, Yarsha Khola catchment 115

3.59: Daily discharge at Site 1, Yarsha Khola catchment 116

3.60: Comparison of daily runoff at Sites 1 of Yarsha and Jhikhu Khola catchments 116

3.61: Relationships between (a) catchment area and average mean annual daily discharge; or (b) average maximum annual daily discharge

3.62: Annual specific yields of different sub-catchments in the Jhikhu Khola and Yarsha Khola catchments 
3.63: Hydrological regime in the Jhikhu Khola catchment (a) and the Yarsha Khola catchment (b) (period 1998 to 2000)

3.64: Flow recession curves in the Jhikhu Khola

3.65: Location of the monitored dug wells in the Jhikhu Khola catchment 120

3.66: Depth of the water table at selected well $(a-e)$ and rainfall at Site $12(f)$

3.67: Variation in depth of the water table in selected wells 122

3.68: Duration curve for Site 1 in the Jhikhu Khola catchment 123

3.69: Duration curve for Site 1 in the Yarsha Khola catchment 123

3.70: Theoretical and empirical design flows for Site 1 in the Jhikhu Khola 124

3.71: Average annual rainfall versus average annual runoff from different sub-catchments in the Jhikhu Khola and Yarsha Khola catchments in comparison with other catchments 127

3.72: Site hierarchy for event analyses

3.73: Precipitation and runoff event parameters

3.74: Relative frequency of events of different rainfall amounts

3.75: 1 st (25\%), 2nd (50\%) and 3rd (75\%) quartiles for event amount [in $\mathrm{mm}$ ] and maximum 10-min intensity [mm/10 min] distribution for all events at all sites

3.76: 1 st (25\%), 2nd (50\%) and 3rd (75\%) quartiles for event amount [in $\mathrm{mm}]$ and maximum 10-min intensity [ $\mathrm{mm} / 10 \mathrm{~min}]$ distribution of large events at all sites

3.77: Rainfall events classified according to rainfall amount

3.78: 1 st (25\%), 2nd (50\%) and 3rd (75\%) quartiles for event amount [in $\mathrm{mm}$ ] and maximum 10-min intensity [ $\mathrm{mm} / 10 \mathrm{~min}]$ distribution for large pre-monsoon and monsoon events at all sites

3.79: 1st (25\%), 2nd (50\%) and 3rd (75\%) quartiles for event amount [in $\mathrm{mm}$ ] and maximum 10-min intensity [mm/10 min] distribution for the 10 largest events at all sites

3.80: Daily rainfall in relation to $I_{10 \max }, I_{30 \max }$ and $I_{60 \max }$ for Sites 4 and 14, Jhikhu Khola catchment

3.81: Dendrogramme of rainfall variables, Site 14, Jhikhu Khola catchment

3.82: Rainfall events' distribution according to the different seasons and clusters

3.83: Event parameters (first, second, and third quartile) for runoff distribution of all events on the erosion plots in the Jhikhu Khola catchment

3.84: Quartiles of the runoff coefficient distribution of the runoff events on the erosion plots of the Jhikhu Khola catchment

3.85: Monthly distribution of runoff coefficients on Plot 6 (agricultural land) and Plot 14 (degraded land)

3.86: Annual cumulative curves for runoff on all erosion plots, Jhikhu Khola 38

3.87: Event parameters (first, second and third quartile) for runoff distribution of the ten largest runoff events on the erosion plots in the Jhikhu Khola catchment

3.88: Five runoff events measured at all sites with similar rainfall conditions

3.89: Daily rainfall versus daily runoff on degraded plots (Sites 4 and 14) and on rainfed agricultural land (Sites 6 and 16). Note: graphs are in log-log scale

3.90: Relationship between runoff and the rainfall clusters

3.91: Impact of land management on runoff generation

3.92: Multiple regressions for Plots $4 \mathrm{a}$ and $14 \mathrm{a}$ on degraded land

3.93: Event runoff (a) and peak event runoff (b) at different sites in the Jhikhu Khola catchment

3.94: Event runoff of pre-monsoon events (a) and monsoon events (b) at all sites in the Jhikhu Khola catchment

3.95: Event runoff (a) and peak event runoff (b) during the ten largest events at each site, Jhikhu Khola catchment

3.96: Dendrogramme for hydrological event parameters at Site 2, Jhikhu Khola catchment

3.97: Antecedent precipitation in comparison with discharge clusters

3.98: Event runoff $Q_{E}$ with rainfall clusters at different sites in the Jhikhu Khola catchment

3.99: Peak event runoff $Q_{E \max }$ with rainfall clusters at different sites in the Jhikhu Khola catchment

3.100: Relationships between erosion plot runoff and sub-catchment runoff

3.102: Relative frequency of rainfall events in the Yarsha Khola catchment 
3.103: 1 st (25\%), 2nd (50\%) and 3rd (75\%) quartiles for event amount [in mm] and maximum 10-min intensity $[\mathrm{mm} / 10 \mathrm{~min}]$ distribution for all events at selected sites

3.104: 1st (25\%), 2nd (50\%) and 3rd (75\%) quartiles for event amount [in mm] and maximum 10-min intensity $[\mathrm{mm} / 10 \mathrm{~min}]$ distribution of large events at selected sites

3.105: 1st (25\%), 2nd (50\%) and 3rd (75\%) quartiles for event amount [in $\mathrm{mm}$ ] and maximum 10-min intensity [mm/10 $\mathrm{min}]$ distribution for large pre-monsoon and monsoon events at selected sites

3.106: 1 st (25\%), 2nd (50\%) and 3rd (75\%) quartiles for event amount [in $\mathrm{mm}$ ] and maximum 10-min intensity [mm/10-min] distribution for the 10 largest events at selected sites

3.107: Distribution of rainfall events according to the different seasons and clusters

3.108: Event parameters (1st, 2nd \& 3rd quartile) for runoff distribution of all events on the erosion plots in the Yarsha Khola catchment

3.109: Quartiles of the runoff coefficient distribution of the runoff events on the erosion plots of the Yarsha Khola catchment

3.110: Monthly distribution of runoff coefficients on all plots in the Yarsha Khola catchment

3.111: Annual cumulative runoff curves for all erosion plots, Yarsha Khola catchment

3.112: Event parameters (1st, 2nd and 3rd quartile) for runoff distribution of the 10 largest runoff events on the erosion plots in the Yarsha Khola catchment

3.113: Relationship between runoff from the erosion plots and the rainfall clusters, Yarsha Khola catchment

3.114: Event runoff (a) and peak event runoff (b) at different sites in the Yarsha Khola catchment

3.115: Event runoff of pre-monsoon events (a), and monsoon events (b) at all sites in the Yarsha Khola catchment

3.116: Event runoff (a) and peak event runoff (b) during the 10 largest events at each site, Yarsha Khola catchment

3.117: Antecedent precipitation in comparison with discharge clusters

3.118: Event runoff $Q_{E}$ with rainfall clusters at Sites 5 and 7 in the Yarsha Khola catchment

3.119: Peak event runoff $Q_{E \max }$ with rainfall clusters at Sites 5 and 7 in the Yarsha Khola catchment

3.120: Linear relationships between selected morphometric and topographic catchment characteristics and hydrological event parameters

3.121: Linear relationships between selected land use catchment characteristics and hydrological event parameters

3.122: The largest flood events at Site 1, Jhikhu Khola catchment

3.123: Antecedent precipitation conditions of the largest events

3.124: Spatial rainfall during the 10 largest events in the Jhikhu Khola catchment

3.125: Rainfall parameters during the largest events in the Jhikhu Khola catchment

3.126: Runoff during the largest events in the Jhikhu Khola catchment

3.127: Sub-catchment runoff during the largest events at the outlet of the Jhikhu Khola catchment

3.128: The ten largest events at Site 1, Yarsha Khola catchment

3.129: Antecedent precipitation conditions of the largest events

3.130: Spatial rainfall during the 10 largest events in the Yarsha Khola catchment

3.131: Rainfall parameters during the largest events in the Yarsha Khola catchment 198

3.132: Runoff during the largest events in the Yarsha Khola catchment 199

3.133: Suspended sediment delivery for some Himalayan rivers

3.134: Empirical relationship between altitude, weathering, transport rate and deposition rate observed in the Jhikhu Khola catchment (from MRE 2002)

3.135: Erosive processes in the Jhikhu Khola catchment

3.136: Geomorphological processes on the south-facing slope of the Yarsha Khola catchment

3.137: Seasonal soil loss Jhikhu Khola

3.138: Monthly soil loss Jhikhu Khola

3.139: Average cumulative soil loss of four plots in the Jhikhu Khola catchment, 1998, 1999, and 2000; and average for 1998-2000 
3.142: Average cumulative soil loss of four plots in the Yarsha Khola catchment, 1998, 1999, 2000 and average for 1998 to 2000

3.143: Event soil loss for a) all events, b) all pre-monsoon and monsoon events of the entire study period, Jhikhu Khola catchment

3.144: Event soil loss for a) all events of the period 1998 to 2000, b) pre-monsoon and monsoon events of the period 1998 to 2000, Jhikhu Khola catchment

3.145: Ten largest events for a) all available data, b) period 1998 to 2000, Jhikhu Khola catchment

3.146: Comparison with precipitation clusters

3.147: Event soil loss for a) all events, b) all pre-monsoon and monsoon events for the period 1998 to 2000, Yarsha Khola catchment

3.148: Ten largest events for the period 1998 to 2000, Yarsha Khola catchment 213

3.149: Comparison with precipitation clusters 214

3.150: Overview of seasonal sediment concentrations at all sites, Jhikhu Khola catchment 217

3.151: Relationship between sediment concentration and catchment area in the Jhikhu Khola catchment

3.152: Overview of seasonal sediment concentrations at all sites, Yarsha Khola catchment 219

3.153: Relationship between sediment concentration and catchment area in the Yarsha Khola catchment

3.154: Cropping calendar in the selected catchments a) Jhikhu Khola, b) Yarsha Khola

3.155: Public water sources documented in the Jhikhu Khola catchment (December 1999) and the Yarsha Khola catchment (May 2000)

3.156: The catchment as a hydrologic system

3.157: Average water surplus and deficits at selected sites in the Jhikhu Khola (period 1993-2000)

3.158: Water surplus and deficit during the study period at Site 6, Jhikhu Khola catchment 239

3.159: Water surplus and deficits at selected sites in the Yarsha Khola (period 1998-2000) 240

3.160: Lapse rates of water deficit a) Jhikhu Khola catchment, b) Yarsha Khola catchment 241

3.161: Lapse rates of water surplus a) Jhikhu Khola catchment, b) Yarsha Khola catchment 241

3.162: Isolines of average water surplus (a) and water deficit (b) in the Jhikhu Khola catchment 241

3.163: Isolines of average water surplus (a) and water deficit (b) in the Yarsha Khola catchment 242

3.164: Average hydrological water balance in the Jhikhu Khola (a), and the Yarsha Khola (b) catchments

3.165: Average hydrological water balance in the sub-catchments of the Jhikhu Khola

3.166: Water accounting diagrams of Jhikhu Khola and Yarsha Khola catchments

4.1: Soil moisture model in UBC catchment model 257

4.2: Schematic diagram of the Tank model 258

4.3: Schematic representation of the soil and runoff generation modules of the PREVAH model

4.4: Monthly mean discharge on the basis of observed and simulated flows using the UBC model

4.5: Daily observed and simulated flows using the UBC model 263

4.6: Observed and simulated duration curve using UBC model 264

4.7: Daily observed and simulated flows using the Tank model 265

4.8: Observed and simulated duration curve using the Tank model 265

4.9: Monthly mean discharge on the basis of observed and simulated flows using the Tank model

4.10: Observed and simulated daily discharge at the main station, Jhikhu Khola catchment 268

4.11: Observed and simulated (PREVAH) monthly mean discharge at the main station of the Jhikhu Khola catchment

4.12: Observed and simulated (PREVAH) duration curves at the main station of the Jhikhu Khola catchment: a) duration curves, b) comparison of duration curves

4.13: Comparison of simulated daily discharge of UBC, Tank, and PREVAH models

4.14: Change in temperature relative to model's global mean

4.15: Seasonal changes with global climate change applying a) PREVAH model, b) Tank model 
4.16: Comparison of duration curves for 1990s and 2080s using a) PREVAH model,

b) Tank mode

4.17: Projected water demand in 2080 in the VDCs of the Jhikhu Khola catchment 278

4.18: Comparison of maxima $\quad 280$

5.1: $\quad$ Water availability in a theoretical catchment 283

5.2: $\quad$ Conceptual framework of water availability in middle mountain catchments of the $\mathrm{HKH} 284$

5.3: $\quad$ Conceptual framework of flood generation and water-induced degradation in middle mountain catchments of the $\mathrm{HKH}$

5.4: $\quad$ Navigation main sheet for water resource assessment in HKH catchments 293

5.5: WPI, FGI, and WDI of the Jhikhu Khola catchment 294

5.6: $\quad$ WPI, FGI, and WDI of the Yarsha Khola catchment 294

5.7: The WPI, FGI, and WDI in the Jhikhu and Yarsha Khola catchments 295

5.8: Impact of the rural development project (a) and climate change (b) on the WPI in the Jhikhu Khola catchment $\quad 297$

5.9: $\quad$ The preliminary WPI in four PARDYP catchments 298

5.10: Zones of different water sources in a hypothetical catchment 299

5.11: Temporal distribution of selected water resource components (a, and Comparison with perceived water shortage (b)

5.12: Comparison of temporal distribution of selected water resource components with crops on a) irrigated land and b) rainfed agricultural land

5.13: Temporal distribution of selected water resource components related to domestic water supply

5.14: Temporal distribution of selected water resource components relevant to soil loss 303

6.1: $\quad$ Water and erosion studies in a watershed management research project 314 


\section{List of Tables}

1.1: Key issues in the HKH related to water 3

1.2: Water related key issues at the catchment scale, PARDYP catchments 4

1.3: Water availability of selected countries in the $\mathrm{HKH}$

1.4: $\quad$ Criticality ratio for selected countries of the $\mathrm{HKH} \quad 5$

1.5: $\quad$ Sanitation coverage $\quad 7$

1.6: Impact of land-use changes at different scales on various water-related parameters 11

2.1: $\quad$ Discharge of the main rivers in the HKH 27

2.2: $\quad$ Brief overview of the PARDYP study sites in Nepal 33

2.3: $\quad$ River-related catchment characteristics $\quad 37$

2.4: $\quad$ Summary of morphometric catchment characteristics 41

2.5: $\quad$ Land-use related catchment characteristics $\quad 44$

2.6: Ratio of cultivated/uncultivated and rainfed/irrigated land for all catchments 45

2.7: $\quad$ Current trends for land-use change 46

2.8: $\quad$ Livestock numbers and stocking density in the Jhikhu and Yarsha Khola catchments 47

2.9: Agronomic intensity $\quad 47$

2.10: Summary of land-use related catchment characteristics 47

2.11: Red and non-red soils in the catchments 49

2.12: Summary of biophysical catchment characteristics 5

2.13: Summary of population and socioeconomic characteristics $\quad 51$

2.14: Hydrological data collection methods and instruments in JK and YK

2.15: Meteorological data collection methods and instruments in JK and YK

2.16: Hydrological station network of the Jhikhu Khola catchment 56

2.17: Meteorological station network of the Jhikhu Khola catchment 56

2.18: Erosion plot network in the Jhikhu Khola catchment 56

2.19: Hydrological station network of the Yarsha Khola catchment 57

2.20: Meteorological station network of the Yarsha Khola catchment 57

2.21: Erosion plot network of the Yarsha Khola catchment 58

3.1: Test statistics for comparison of the short-term with the long-term records 64

3.2: $\quad$ Statistics of annual rainfall in the Jhikhu Khola catchment 66

3.3: $\quad$ Seasonal rainfall in the Jhikhu Khola catchment, 1993-2000 [\%] 67

3.4: Precipitation with potential for runoff generation and sediment mobilisation,
Jhikhu Khola catchment [in \% from the total rainfall]

3.5: $\quad$ Statistics of annual rainfall in the Yarsha Khola $\quad 72$

3.6: Seasonal rainfall in the Yarsha Khola catchment, 1998 - 2000 [\%] 73

3.7: Precipitation with potential for runoff generation and sediment mobilisation,

3.8: Differences in mean, maximum and minimum monthly rainfall due to aspect of

$\begin{array}{lll}\text { 3.9: } & \text { Stations on the upper and on the lower slopes, Jhikhu Khola catchment } & 81 \\ & \text { Differences in rainfall amount due to aspect } & 83\end{array}$

3.10: Average monthly relative frequencies at all sites [\%] (black = maximum) 86

3.11: $\quad$ PMP calculated according to Hershfield for different sites in the Jhikhu Khola catchment 90

3.12: PMP calculated according to Hershfield for different sites near the Yarsha Khola catchment

3.13: Mann-Kendall test statistics for trend of mean annual rainfall in the Jhikhu Khola catchment

3.14: Linear trend test statistics for annual mean in the Jhikhu Khola catchment 93

3.15: Mann-Kendall test statistics for trends around the Yarsha Khola catchment 93

3.16: Temperature lapse rates in the Jhikhu Khola catchment: for mean (maximum, minimum) temperatures [ $\left.{ }^{\circ} \mathrm{C} / 100 \mathrm{~m}\right] \quad 97$

3.17: Temperature lapse rates in the Yarsha Khola catchment: for mean (maximum, minimum) temperatures $\left[{ }^{\circ} \mathrm{C} / 100 \mathrm{~m}\right]$

3.18: Mean daily $\mathrm{ET}_{0}$ for different sites in the Jhikhu and Yarsha Khola catchments [mm/day]

3.19: Annual lapse rates for $\mathrm{ET}_{0}[\mathrm{~mm} / 100 \mathrm{~m}] \quad 103$

3.20: Average crop coefficient $K_{c}$ for different land uses $\quad 105$

3.21: Areal AET in the Jhikhu Khola catchment for the period from 1993to 2000 calculated by FAO (1998) and Thornthwaite and Mather (1955) (T\&M) [mm] 
3.22: Areal AET in the Yarsha Khola catchment for the period from 1998 to 2000 calculated by FAO (1998) and Thornthwaite and Mather (1955) (T\&M) [mm]

3.23: Annual runoff at the plots in the Jhikhu Khola catchment

3.24: Annual runoff [mm]

3.25: Annual principal discharge figures for site 1, Jhikhu Khola catchment

3.26: Annual principal discharge figures for site 1, Yarsha Khola catchment

3.27: Storage of different water bodies

3.28: Critical values of deficit and exceedance, Site $1 \mathrm{Jhikhu}$ Khola catchment

3.29: Critical values of deficit and exceedance at Site 1, Yarsha Khola catchment [m3/s]

3.30: Comparison of theoretical design flows on the basis of different distributions, Site 1, Jhikhu Khola catchment

3.31: Mann-Kendall test statistics for trend of flow parameters at Site 1 in the Jhikhu Khola catchment (period 1993 to 2000)

3.33: Events at selected sites 131

3.34: Median of different event parameters considering all events 132

3.35: Median for selected rainfall parameters of large events 133

3.36: Rainfall event parameters (median) for large pre-monsoon and monsoon events $\quad 135$

3.37: Rainfall event parameters (median) for the ten largest events 136

3.38: Correlations at Site 6 with number of sites with significant correlations at all sites in brackets

3.39: Key variables (ar) for precipitation, Jhikhu Khola catchment

3.40: Cluster centres of different parameters at different sites

3.41: Final clusters for rainfall event classification, Jhikhu Khola catchment 139

3.42: Annual frequencies of different events classified according to clusters 140

3.43: Erosion plot events in the Jhikhu Khola catchment 142

3.44: Medians of all runoff events on the erosion plots, Jhikhu Khola catchment 142

3.45: Median all PM and M events 143

3.46: Median of the largest 10 runoff events, Jhikhu Khola catchment 145

3.47: Correlation coefficients for plot runoff - Summary of the four erosion plots in the Jhikhu Khola catchment

3.48: Plot and soil characteristics

3.49: Infiltration rates calculated from rainfall events $t_{p}<60 \mathrm{~min}, I_{\text {ave }}>10 \mathrm{~mm} / \mathrm{h}$ and $P_{\text {tot }}>5 \mathrm{~mm}$

3.50: Example for farmer's activities on the plot 16a in 1998

3.52: Events at all sites in the Jhikhu Khola catchment 152

3.53: Median of all parameters for hydrological events, Jhikhu Khola 153

3.54: Median of pre-monsoon and monsoon hydrological events, Jhikhu Khola 153

3.55: Median of maximum ten hydrological events, Jhikhu Khola 154

3.56: Correlation coefficients at Site 2 and number of significant correlations at all four sub-catchments, Jhikhu Khola (maximum = 4; Appendix A3-16) 155

3.57: Results of the factor analyses for hydrological parameters of all events, Jhikhu Khola 155

3.58: Discharge event parameter clusters $\quad 156$

3.59: Final cluster 157

3.60: Correlation coefficients of hydrological parameters with respect to antecedent precipitation conditions at Site 2 and number of significant correlations in brackets, Jhikhu Khola catchment

3.61: Results of the factor analyses for antecedent precipitation characteristics, Jhikhu Khola 158

3.62: Correlation of discharge event with rainfall event parameters at Site 2 and number of significant correlations at all sites, Jhikhu Khola catchment

3.63: Pearson and Spearman correlation coefficients between clusters of different origin $\quad 160$

3.64: Correlation coefficients for runoff from the plots with event parameters at the sub-catchment outlet

3.65: Events at selected sites 163

3.66: Median of different event parameters considering all events 164

3.67: Median for selected rainfall parameters of large events 165 
3.68: Rainfall event parameters (median) for large pre-monsoon and monsoon events

3.69: Rainfall event parameters (median) for 10 largest events in the Yarsha Khola catchment 166

3.70: Rainfall event parameter correlation analysis for Site 6 and number of significant correlations for all sites in brackets

3.71: Key variables ( - ) for precipitation, Yarsha Khola catchment

3.72: Cluster centres of different parameters at different sites, Yarsha Khola catchment 168

3.73: Final clusters for rainfall events, Yarsha Khola catchment

3.74: Annual frequencies of events of different clusters

3.75: Events on the erosion plots

3.76: Medians of all runoff events on the erosion plots in the Yarsha Khola catchment

3.77: Medians of pre-monsoon and monsoon runoff events on the erosion plots in the Yarsha Khola catchment

3.78: Median of the 10 largest runoff events, Yarsha Khola catchment

3.79: Correlation coefficients for runoff - Summary of the four erosion plots in the Yarsha Khola catchment

3.80: Plot and soil characteristics

3.81: Infiltration rates calculated from rainfall events $t_{P}<60 \mathrm{~min}, I_{\text {ave }}>10 \mathrm{~mm} / \mathrm{h}$ and $P_{\text {tot }}>5 \mathrm{~mm}$

3.82: Events at all sites in the Yarsha Khola catchment

3.83: Median of all parameters for hydrological events, Yarsha Khola 177

3.84: Median of pre-monsoon and monsoon hydrological events, Yarsha Khola 178

3.85: Median of 10 maximum hydrological events, Yarsha Khola 179

3.86: Correlation coefficients at Site 7 and number of significant correlation in backets, Yarsha Khola

3.87: Results of the factor analyses for hydrological parameters of all events, Yarsha Khola

3.88: Centres of discharge event parameter clusters, Yarsha Khola catchment 180

3.89: Final clusters for discharge events, Yarsha Khola catchment 181

3.90: Correlation coefficients of hydrological parameters with respect to antecedent precipitation conditions at Site 7 and number of significant correlations in brackets 181

3.91: Results of the factor analyses for antecedent precipitation characteristics, Yarsha Khola 182

3.92: Correlation of discharge event with rainfall event parameters at Site 7 and number of significant correlations at both sites

3.93: Rainfall cluster of the Jhikhu Khola and Yarsha Khola catchments

3.94: Spearman correlation coefficients $r$ for morphometric and topographic catchment characteristics in relation to hydrological event characteristics

3.95: Spearman correlation coefficients $r$ for land-use related catchment characteristics in relation to hydrological event characteristics

3.96: Hydrological event parameters for largest events at Site 1, Jhikhu Khola catchment

3.97: Rainfall clusters for the rainfall events triggering the largest flood events in the Jhikhu Khola catchment

3.98: Rank of flood events in the sub-catchments during the time of the largest events at Site 1, Jhikhu Khola catchment

3.99: Hydrological event parameters for largest events at Site 1, Yarsha Khola catchment

3.100: Rainfall clusters for the rainfall events triggering the largest flood events in the Yarsha Khola catchment

3.101: Priorities of the occurrence of erosive processes and their importance as sediment sources in the Jhikhu and Yarsha Khola catchments (rating 1 to 5)

3.102: Annual soil loss [t/ha] (in brackets the annual rainfall in $\mathrm{mm}$ at the plot)

3.103: Annual soil loss [t/ha] (in brackets the annual rainfall in $\mathrm{mm}$ at the plot)

3.104: Correlation coefficients of significant correlations between event soil loss and selected parameters

3.105: Correlation coefficients between soil loss and selected parameters

3.106: Comparison of annual soil losses [ $t / h a$ ] of PARDYP Nepal data with other sources

3.107: Number of sediment samples in the Jhikhu Khola and Yarsha Khola catchments

3.108: Empirical sediment concentrations at different discharge on the basis of the above sediment rating curves in Figure 3.150, Jhikhu Khola catchment

3.109: Empirical sediment concentrations at different discharge on the basis of the above sediment rating curves, Yarsha Khola catchment 
3.110: Seasonal sediment loads of the Jhikhu and Yarsha Khola catchments, 1998-1999 (mean \pm standard deviation)

3.111: Correlation coefficients according to Spearman of sediment yield per unit area with selected catchment characteristics

3.112: Estimated sediment production (normal regime) at the outlet of the Jhikhu and Yarsha Khola catchments

3.113: Calculation of SDR

3.114: Water demand for domestic use 225

3.115: Water requirements of the main crops in the Jhikhu Khola 227

3.116: Water requirements of the main crops in the Yarsha Khola 227

3.117: Water demand for watering livestock 229

3.118: Overall water demand of human activities 229

3.119: Water-related problems, Yarsha Khola and Jhikhu Khola catchments 229

3.120: Description of service level for water supply 231

3.121: Seepage in irrigation canals 232

3.122: Mean annual water surplus and deficit 239

3.123: Annual water surplus and deficit at selected sites in the Yarsha Khola catchment 239

3.124: Water-accounting components of the Jhikhu Khola and Yarsha Khola catchments 245

3.125: Water-accounting indicators for the Jhikhu Khola and Yarsha Khola catchments 245

4.1: Compilation of the main characteristics of the models used 356

4.2: $\quad$ Data used for modelling 361

4.3: Efficiency of the UBC catchment model on the basis of daily data 362

4.4: Efficiency of the tank model on the basis of daily data 366

4.5: Input data information for the application of the PREVAH model 367

4.6: Parameters calibrated for the PREVAH model 367

4.7: Assessment of performance of the PREVAH model 368

4.8: Efficiency parameters compared between the three models 270

4.9: Correlation matrix for daily discharge simulated with different models 270

4.10: Climate change parameters (by 2080) 273

4.11: Population and water demand parameters (by 2080) 274

4.12: Land-use change parameters (by 2080) 275

4.13: Community forest areas in the Jhikhu Khola catchment 275

4.14: Number of peaks $>10 \mathrm{~m} 3 / \mathrm{s}$ for 1990 s and 2080s with different models 277

4.15: Projected population and water demand Jhikhu Khola catchment, 2080

4 16: Land-use changes on the basis of the land-use scenarios 279

417: Comparison of the PREVAH outputs with scenarios Landflucht $1 \& 2$ and

51: Explanations for theoretical index extremes 289

5 2: Indicators for the Water Poverty Index 290

53: Example for the calculation of the sub-index access of the WPI 291

5 4: Indicators for the Flood Generation Index 292

5 5: Indicators for the Water Induced Degradation Index 292

5 6: Parameter values before and after the selected impact 296 